\title{
STUDIES OF N-ALKANES IN THE SEDIMENTS OF COLONY Z3 (PELOTAS - RS - BRAZIL)
}

\author{
SANCHES FILHO, P.J. ${ }^{1 *}$; LUZ, L. P. ${ }^{1}$; BETEMPS, G.R. ${ }^{1}$; SILVA, M. D. R. G. ${ }^{2}$ \& CARAMÃO, E. B. ${ }^{3}$ \\ 1 - Instituto Federal de Educação, Ciência e Tecnologia Sul-Rio-Grandense \\ 2 - REQUIMTE, DQ, Faculty of Sciences and Technology, Universidade Nova de Lisboa \\ 3 - Universidade Federal do Rio Grande do Sul \\ *Corresponding author: pjsans@ibest.com.br
}

\begin{abstract}
Sanches Filho, P.J.; Luz, L. P.; Betemps, G.R.; Silva, M. D. R. G. \& Caramão, E. B. (2013) Studies of n-alkanes in the sediments of Colony Z3 (Pelotas - RS - Brazil). Braz. J. Aquat. Sci. Technol. 17(1):27-33. elSSN 1983-9057. DOI:10.14210/bjast.v17.n1.p27-33. This paper investigates the presence and concentration levels, of $n$-alkanes and also the potential sources of contamination of surface sediments in the fishing village Z-3 in the city of Pelotas, Brazil. The extraction of the sediments was performed according to EPA method 3540 and the separation of aliphatic hydrocarbons was done with preparative column chromatography. Gas chromatographic analysis with flame ionization detector was employed for the identification and quantification of compounds The level of aliphatic hydrocarbons found, was due mainly to $n$-alkanes originated from weathering of terrestrial plants and algae production. It is also possible to observe the dilution effect of the lagoon about analyzed compounds, comparing the results obtained from different sampling points. In general, the sediments sampled in the investigated region presented small levels of contamination by hydrocarbons.
\end{abstract}

Key words: Hydrocarbons, Patos Lagoon, Chromatographic Analysis.

\section{INTRODUCTION}

Numerous coastal ecosystems have been affected by treated or untreated wastewater discharges, both of urban and industrial origin. Estuarine areas serve as receptors of natural and anthropogenic organic matter derived from land and carried there by the rivers and the air (Wu et al., 2001).

Coastal areas have received a significant input of hydrocarbons, land-derived organic compounds (Pereira et al., 1999; Wu et al., 2001). The analysis of these substances in the aquatic environment can be done on samples taken from water, organisms and sediments (Medeiros et al., 2005). Sediments are recognized to be excellent sinks for pollutants such as hydrocarbons. These compounds are readily adsorbed onto particulate material, and bottom sediments act as a reservoir of hydrophobic contaminants (Volkman et al., 1992). Therefore, sediments can hold and release pollutants, causing detrimental effects to the biota long after the initial input of pollution has ceased. These contaminants may be released slowly and they may also accumulate in organisms that dwell in and around the sediment (Tolosa et al., 2005). The composition of hydrocarbon compounds found in sediments reflects relatively the origin of such compounds: biogenic, diagenetic, petrogenic and pyrogenic (Wu et al., 2001; Azevedo et al., 2002; Mille et al., 2005). Aliphatic hydrocarbons in sediments derive from a variety of allochthonous sources, mainly higher plants, and autochthonous sources, including plankton and bacteria (Wakeham, 1996). The characteristic molecular com- position often provides the means for distinguishing between sources.

Among the biogenic hydrocarbons, $n$-alkanes are the ones predominant in plants and animals (Nishigima et al., 2001). Biogenic hydrocarbons are typically characterized by homologous series of shortchain $n$-alkanes (e.g., nC15 - nC19) if derived from algae or longer-chain $n$-alkanes (nC25-nC35), if derived from higher plant epicuticular waxes, coupled with a strong predominance of odd-over-even carbon numbers (Yunker et al., 1993). Aliphatic hydrocarbons are also the major components of petroleum products, producing a distribution of $n$-alkanes in which odd and even carbon chain lengths are roughly equal in abundance (yielding a carbon preference index [CPI] of $\approx 1$ ) and often with an unresolved complex mixture (UCM) of branched and cyclic alkanes (Colombo et al., 1989; Martins et al., 2004; Simpson et al., 2005; Zheng \& Richardson, 1999).

Patos Lagoon is the largest lagoon in Brazil, and it receives most of the drainage system of the Rio Grande do Sul state. This is a bar - built lagoon with an estuarine area of about $900 \mathrm{~km}^{2}$, and it has been exposed to significant anthropogenic effects mainly originated by the industrial and the port dwelling areas of Rio Grande City. The Patos Lagoon $\left(32^{\circ} \mathrm{S}, 49^{\circ} \mathrm{W}\right)$ is ca. $250 \mathrm{~km}$ long and $60 \mathrm{~km}$ wide, covering an area of $10360 \mathrm{~km}^{2}$ along the coastal plain of Rio Grande do Sul in southern Brazil (Figure 1). This lagoon is one of the world's largest coastal aquatic ecosystems with a drainage basin of $201626 \mathrm{~km}^{2}$. The lagoon is connected to the ocean via a channel bordered by jetties, $4 \mathrm{~km}$ 
long and $740 \mathrm{~m}$ wide, that were constructed to stabilize the mouth of the estuary and to allow navigation along the entrance channel (Figure 1). The estuarine zone serves as a nursery ground for coastal fishes, including species that support important fisheries in the southwestern Atlantic Ocean (Tagliani et al., 2003). More than 3000000 inhabitants live in the surrounding towns and cities, using the waters of the pond for fishing, agriculture, industry, navigation, domestic consumption and leisure (Mirlean et al., 2003). Z3 is a fishing village located $20 \mathrm{~km}$ from the city of Pelotas on the margin west of the Patos Lagoon. This village was founded in 1923 and it is a traditional nucleus of craft fishermen.

The majority of the studies related to the Patos Lagoon has focused on the quality and composition of the water, organic matter and nutrient enrichment (Baumgarten et al., 2001). Most research of investigations addressing hydrocarbons in the Patos Lagoon, were conducted in the area of the city of Rio Grande (Cordeiro, 2003).

This paper investigates the levels of hydrocarbons and also the potential sources of contamination of the sediments in the fishing village (Z-3) in the city of Pelotas, Brazil. The main objective of this study was to assess the relative contribution of waste fuel and biogenic hydrocarbons to the surface sediments in this area.

\section{MATERIALS AND METHODS}

In order to evaluate hydrocarbons inputs from natural and anthropogenic sources to Patos Lagoon (Z-3 Village), four sediment samples were collected in February 2007 (summer) in the sites shown in Figure 1.

The exact position of each sampling point (Table 1) was defined through GPS measurements (GPS, Global Positioning System, equipment Garmin \& Trex®, precision of $\pm 15 \mathrm{~m}$ ). These sites are located in a fishing village (Z-3) in the city of Pelotas, (Brazil). Surface (bed load) sediments (0 - $5 \mathrm{~cm}$ deep) were collected utilizing a stainless steel Van Veen grab. Samples were placed in cleaned, solvent rinsed glass flasks wrapped with aluminum foil. All samples were homogenized and immediately frozen after collection at $-4^{\circ} \mathrm{C}$ until laboratory analysis.

Collected sediments were homogenized and sub sampled for the determination of water content, organic matter and grain size distribution. The total organic matter (TOM) was determined by the calcination method (Bisutti et al., 2004) and the grain size analysis by the standard sieve method (Suguio, 1973). The water's temperature, conductivity and $\mathrm{pH}$ to each point were measured at the moment of the sediment

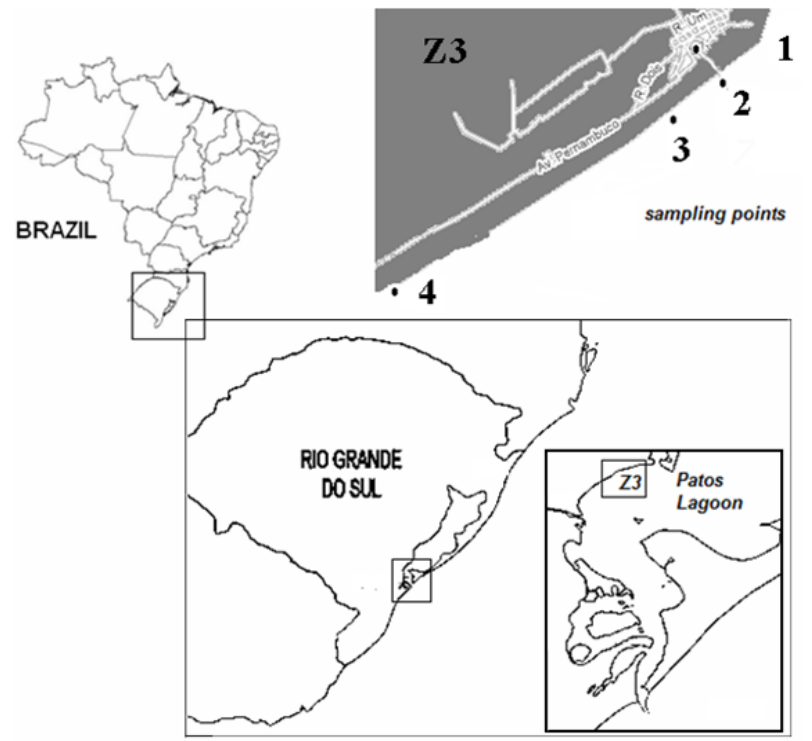

Figure 1 - Map of the Pelotas region and the location of the sampling points.

sampling. The $\mathrm{pH}$ was determined by potentiometric method, using the digital $\mathrm{pH}$ meter mark homis MOD. 801. Conductivity and dissolved oxygen were respectively analyzed by a portable conductivity meter, Instrutherm MOD. CD-830, and by pulse oximetry, homis MOD. 509.

Solvents (dichloromethane - DCM, n-hexane hex and acetone - ace), anhydrous sodium sulfate and silica gel 60 (70-230 mesh ASTM) were of analytical grade from Merck (Darmastadt, Germany); neutral alumina (type 507, 70-290 mesh ASTM) was from Fluka AG (Switzerland) and cellulose extraction cartridges (20 mm i.d. and $80 \mathrm{~mm}$ long) were from Whatman (UK). Silica, alumina and anhydrous sodium sulfate were activated at $400^{\circ} \mathrm{C}$ during 4 hours. Aluminum foils were rinsed with acetone and let dry at environment temperature prior to use.

Copper foils (Sigma-Aldrich, USA) were activated with concentrated $\mathrm{HCl}$ and further washing with purified water (twice), methanol (twice), DCM (twice) and hexane (twice), being stored in hexane.

The chromatographic standards were purchased from Sigma Aldrich (USA). The standard solution of $n$-alkanes hydrocarbons (nC8 - nC40) was obtained by dilution of a $40 \mathrm{mg} \mathrm{L}^{-1}$ standard mixture in dichloromethane.

Extraction of the analytes was carried out using Soxhlet equipment, according to EPA method 3540 (USEPA, 1996). The wet sample $(25 \mathrm{~g})$ was mixed with $25 \mathrm{~g}$ of anhydrous $\mathrm{Na}_{2} \mathrm{SO}_{4}$ and, the analytes, extracted for 16 hours using approximately $250 \mathrm{~mL}$ of a solvent mixture of acetone/hexane $(1: 1, v / v)$. Activated copper foils were added during extraction for sulfur removal (Zheng \& Richardson, 1999) in order to avoid these interferences in the gas chromatography analysis. 
Extracts were passed through a column filled with anhydrous $\mathrm{Na} 2 \mathrm{SO} 4$ and concentrated under a nitrogen flow (99.99\%, White Martins). Further purification of extracts was performed using a column filled with $1 \mathrm{~g}$ of anhydrous $\mathrm{Na}_{2} \mathrm{SO}_{4}, 3.2 \mathrm{~g}$ of silica $\left(\mathrm{SiO}_{2}\right)-5 \%$ deactivated, $1.8 \mathrm{~g}$ of alumina $\left(\mathrm{Al}_{2} \mathrm{O}_{3}\right)-2 \%$ deactivated, and $1 \mathrm{~g}$ of anhydrous $\mathrm{Na}_{2} \mathrm{SO}_{4}$ on the top. Extracts were mixed with $0.5 \mathrm{~g}$ of silica and added on the top of a column. The sequence of solvents for elution was $20 \mathrm{~mL} n$-hexane (fraction F1 - Aliphatic hydrocarbons), $20 \mathrm{~mL}$ of DCM/n-hexane solution (1:5, $\mathrm{v} / \mathrm{v})$ and $20 \mathrm{~mL}$ of $\mathrm{DCM} /$ hexane solution $(1: 1, \mathrm{v} / \mathrm{v})$. Fraction F2 (polyaromatic compounds) resulted from the mixture of these two later fractions (UNEP, 1992). All fractions were concentrated under nitrogen flow and then stored at $-4^{\circ} \mathrm{C}$.

For the chromatographic analysis, the fractions (F1) were reconstituted in DCM (up to $1 \mathrm{~mL}$ ) and one aliquot of $1 \mu \mathrm{L}$ of each extract was injected in the GGFID in splitless mode.

The $n$-alkanes hydrocarbons were quantified using a GC-FID (Focus Thermo Finnigan), with a DB1 column $(30 \mathrm{~m} \times 0.25 \mathrm{~mm}$ i.d. $\times 0.25 \mu \mathrm{L}$ film thickness $)$ and splitless mode injection. Injector and detector were maintained at $2800 \mathrm{C}$ and $3000 \mathrm{C}$, respectively. A calibration curve for $\mathrm{nC} 8$ to $\mathrm{nC} 38$ linear $n$-alkanes hydrocarbons covered a range between 0.2 and $4.0 \mathrm{mg} \mathrm{L}^{-1}$, encompassing five points of different. Each point of the calibration curve represents the mean value of three independent area measurements. The limit of detection (LOD) was calculated using 3 times the standard deviation of the intercept divided by the slope, whereas limit of quantification (LOQ) was calculated using 10 times the standard deviation of the intercept divided by the slope.

Oven temperature program used in both equipments was: initial temperature $80^{\circ} \mathrm{C}, 5 \mathrm{~min}$ on hold, heating to $160^{\circ} \mathrm{C}$ at $8^{\circ} \mathrm{C} \mathrm{min}{ }^{-1}$ and heating to $280^{\circ} \mathrm{C}$ at $3^{\circ} \mathrm{C} \mathrm{min}^{-1}$ (15 min hold). Sample volume injected was $1.0 \mu \mathrm{l}$.
The Carbon Preference Index (CPI) (Commendatore \& Esteves, 2004; Calva et al., 2005; Mille et al., 2007) was used for identifying plant wax contribution versus fossil fuel contamination. CPI can be calculated through the expression:

$$
\mathrm{CPI}=\left(\frac{\sum \text { concentration of odd } \mathrm{HC}}{\sum \text { concentration of even } \mathrm{HC}}\right) \times\left(\frac{\text { number of odd } \mathrm{HC}}{\text { number of even } \mathrm{HC}}\right)
$$

The terrigenous/aquatic ratio (TAR) (Mille et al., 2007) which is the ratio between the concentrations of long-chain $n$-alkanes $(\mathrm{nC} 27+\mathrm{nC} 29+\mathrm{nC} 31)$ vs. shortchain $n$-alkanes $(\mathrm{nC} 15+\mathrm{nC} 17+\mathrm{nC} 19)$ evaluates the importance of terrigenous inputs versus aquatic inputs.

\section{RESULTS AND DISCUSSION}

\section{n-alkanes Hydrocarbons}

A preliminary study of the characterization of sediments from different sampling points can be seen on table 1 and figure 2. Point 1 exhibited sediment richer in organic matter and with a smaller grain size. These characteristics indicate a potential for the accumulation of organic pollutants.

Results of the chromatographic analysis of $n$ alkanes hydrocarbons can be observed in Figure 3 and Tables 2 and 3.

Correlation coefficients $\left(R^{2}\right)$ varied from 0.982 to 1.000; limits of detection (LOD) and limits of quantification (LOQ) were found in the range of $0.11-4.20 \mu \mathrm{g} \mathrm{kg}^{-1}$ and $0.45-5.07 \mu \mathrm{g} \mathrm{kg}^{-1}$, respectively (Table 2).

The samples showed a distribution of $n$-alkanes from $\mathrm{nC} 14$ to $\mathrm{nC} 34$, and the total $n$-alkanes concentrations in the sampling points varied from 337.6 to $5868.9 \mu \mathrm{g} \mathrm{kg}^{-1}$ (Table 3). A decrease in concentration was observed from $\mathrm{P} 1$ to $\mathrm{P} 4$ sites. This behavior is in agreement with the results for analysis of PAHs, constituents of Fraction 2, studied by Luz et al. (2010) and Sanches et al. (2010), in the same area. The

Table 1 - Detailed description and characteristics of sampling sites. Mean \pm RSD relative standard deviation, TOM - total organic matter, C - conductivity, T - Temperature.

\begin{tabular}{|c|c|c|c|c|c|c|c|}
\hline & & & \multicolumn{2}{|c|}{ Sediment } & \multicolumn{3}{|c|}{ Water } \\
\hline & & & $\%$ moisture & $\begin{array}{c}\% \text { TOM } \\
\text { (dry basis) }\end{array}$ & ${ }^{\mathrm{T}} \mathrm{C}$ & $\begin{array}{c}\mathrm{C} \\
\mathrm{mS} . \mathrm{cm}^{-1}\end{array}$ & $\mathrm{pH}$ \\
\hline P1 & “Divinéia” pier & $\begin{array}{l}31^{\circ} 42^{\prime} 03,6^{\prime} \mathrm{S} \\
52^{\circ} 09^{\prime} 19,5^{\prime \prime} \mathrm{W}\end{array}$ & $35.58 \pm 1,57$ & $5.3 \pm 10,0$ & 25 & 16.0 & 6,8 \\
\hline P2 & $\begin{array}{l}\text { output port of the } \\
\text { "Divinéia" into the lagoon }\end{array}$ & $\begin{array}{l}31^{\circ} 42^{\prime} 05,4^{\prime \prime} \mathrm{S} \\
52^{\circ} 09^{\prime} 17,3^{\prime \prime} \mathrm{W}\end{array}$ & $29.88 \pm 2,94$ & $3.0 \pm 5,6$ & 25 & 27,9 & 7,3 \\
\hline P3 & $\begin{array}{l}\text { point within the lagoon in } \\
\text { front of fishermen village }\end{array}$ & $\begin{array}{l}31^{\circ} 42^{\prime} 12,7^{\prime \prime} \mathrm{S} \\
52^{\circ} 09^{\prime} 22,3^{\prime \prime} \mathrm{W}\end{array}$ & $27.65 \pm 3,14$ & $1.6 \pm 6,3$ & 26 & 28,2 & 7,2 \\
\hline P4 & $\begin{array}{l}\text { point within the lagoon - in } \\
\text { front of the municipal } \\
\text { camping }\end{array}$ & $\begin{array}{l}31^{\circ} 42^{\prime} 04,0^{\prime \prime} \mathrm{S} \\
52^{\circ} 10^{\prime} 25,7^{\prime \prime} \mathrm{W}\end{array}$ & $31.56 \pm 3,29$ & $2,0 \pm 4,14$ & 26 & 28,4 & 7,2 \\
\hline
\end{tabular}




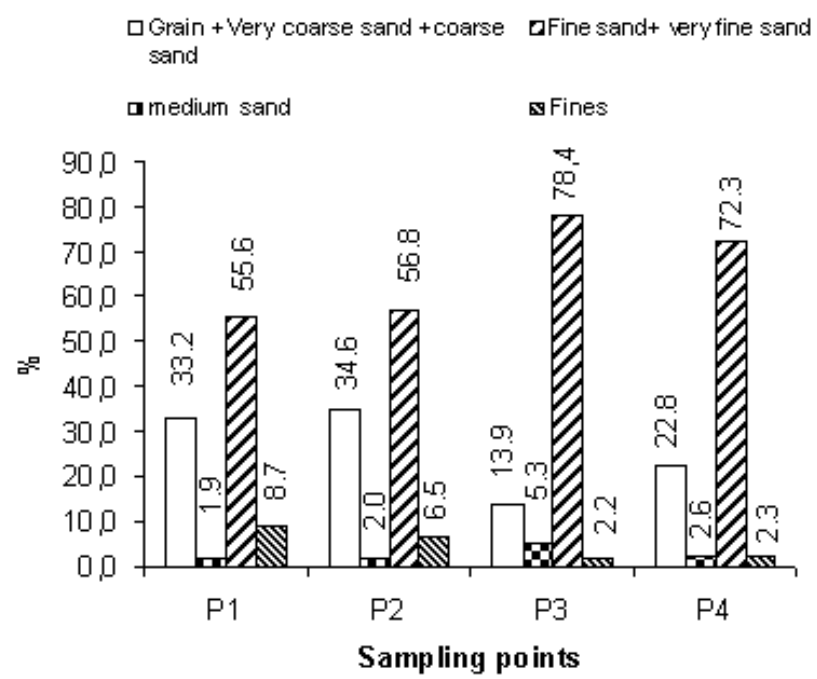

Figure 2 - Particle size distribution for the sediments at each sampling point.

results of this study are also in agreement with those obtained in studies performed in similar regions, as shown in Table 4.

The distribution profiles of the $n$-alkanes from $\mathrm{nC} 19$ to $\mathrm{nC} 32$ in points $\mathrm{P} 2, \mathrm{P} 3$ and P4 are similar, differing from point $P 1$. The major difference between the three sites (especially points $\mathrm{P} 1$ and $\mathrm{P} 2$ ) is in the range from $\mathrm{nC} 14$ to $\mathrm{nC} 18$. This difference can be caused by the presence of compounds originated from phytoplankton and algae.

Unresolved Complex Mixtures (UCM) were detected only in point P1, and they may be due to

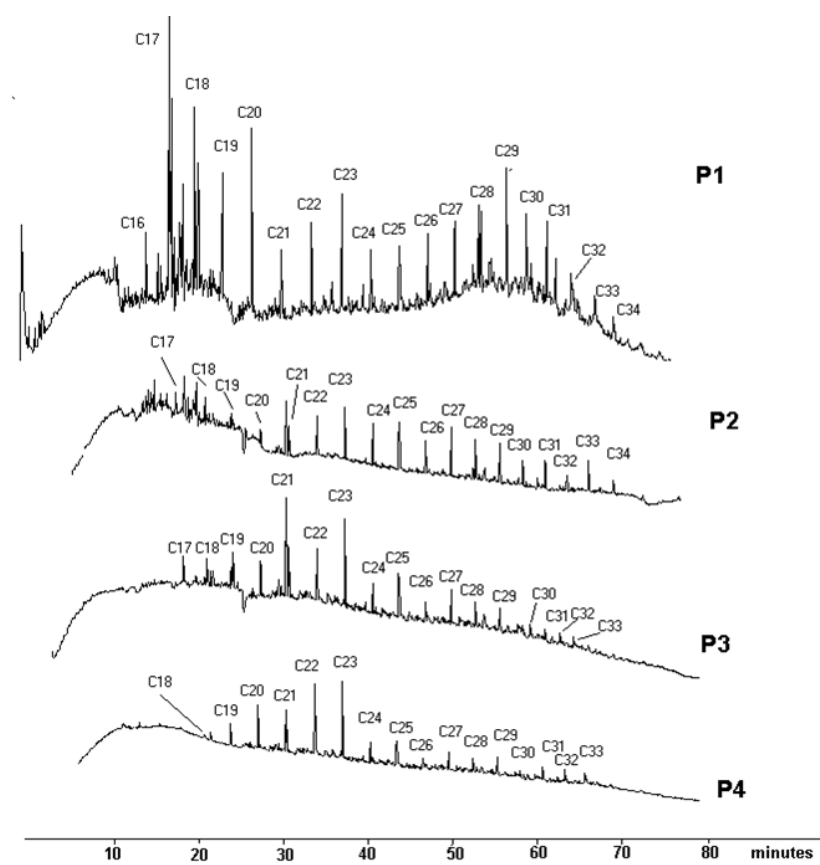

Figure 3 - Gas chromatograms of aliphatic hydrocarbons, characterizing $n$-alkanes in sediments. Chromatographic conditions are reported in the text and all chromatograms are normalized to the signal level at a maximum of $7 \mathrm{mV}$.
Table 2 - Figures of merit for the analytical procedure. a - slope, linear coefficient, $b$ - correlation coefficient, for the equation $Y=a X+b$; LOD- limit of detection; LOQ-limit of quantification.

\begin{tabular}{cccccc}
\hline \hline Compound & $\mathrm{a}$ & $\mathrm{b}$ & $\mathrm{R}^{2}$ & $\begin{array}{c}\mathrm{LOD} \\
\mu \mathrm{g} \mathrm{Kg}\end{array}$ & $\begin{array}{c}\mathrm{LOQ} \\
\mu \mathrm{g} \mathrm{Kg}\end{array}$ \\
\hline C8 & 7729.1 & -957.2 & 0.991 & 3.7 & 5.1 \\
C9 & 138189 & -28524.0 & 0.987 & 4.2 & 4.3 \\
C10 & 10805 & -1229.2 & 0.995 & 3.1 & 4.1 \\
C11 & 9970.4 & -451.8 & 0.993 & 1.8 & 2.9 \\
C12 & 22140 & -1261.0 & 0.998 & 1.6 & 2.0 \\
C13 & 19059 & -1772.8 & 0.991 & 2.4 & 2.9 \\
C14 & 19509 & -1112.6 & 0.993 & 1.6 & 2.2 \\
C15 & 19448 & -807.2 & 0.992 & 1.3 & 1.9 \\
C16 & 20004 & -918.6 & 0.992 & 1.4 & 1.9 \\
C17 & 19945 & -786.9 & 0.996 & 1.3 & 1.8 \\
C18 & 20717 & -1125.0 & 0.996 & 1.5 & 2.1 \\
C19 & 21636 & -1157.4 & 0.996 & 1.5 & 2.0 \\
C20 & 21968 & -1007.4 & 0.997 & 1.3 & 1.8 \\
C21 & 23303 & -552.6 & 0.998 & 0.9 & 1.3 \\
C22 & 22820 & -406.6 & 0.998 & 0.8 & 1.2 \\
C23 & 22334 & 257.8 & 0.997 & 0.2 & 0.7 \\
C24 & 25588 & -776.0 & 0.995 & 1,0 & 1.4 \\
C25 & 24826 & 447.2 & 0.998 & 0.2 & 0.4 \\
C26 & 24394 & -584.4 & 1.000 & 0.9 & 1.3 \\
C27 & 25369 & 315.6 & 0.997 & 0.2 & 0.5 \\
C28 & 26175 & -180.1 & 0.999 & 0.5 & 0.9 \\
C29 & 27613 & 311.2 & 0.997 & 0.1 & 0.5 \\
C30 & 28496 & -20.9 & 0.998 & 0.3 & 0.7 \\
C31 & 28655 & -440.4 & 0.997 & 0.6 & 1.0 \\
C32 & 29034 & -1463.9 & 0.999 & 1.3 & 1.7 \\
C33 & 27667 & -1285.0 & 0.999 & 1.3 & 1.6 \\
C34 & 24968 & -1274.4 & 0.998 & 1.4 & 1.8 \\
C35 & 23503 & -1494.5 & 0.995 & 1.7 & 2.1 \\
C36 & 22163 & -2161.4 & 0.993 & 2.4 & 2.8 \\
C37 & 18919 & -1354.6 & 0.997 & 1.9 & 2.5 \\
C38 & 18388 & -3031.1 & 0.982 & 3.8 & 4.4 \\
\hline \hline
\end{tabular}

petroleum input and/or the presence of biodegraded complex mixture of hydrocarbons, as it can be seen in the chromatograms of Figure 3 . In this sampling point it is possible to observe that the concentration of nC16, nC18, nC20 alkanes, which are characteristic of fossil fuels, is higher than in the other sampling points. The UCM can be considered as the result of many co-elutions of structurally complex isomers and homologues of branched and cyclic hydrocarbons (Mille et al., 2007).

The evaluation of individual $n$-alkanes in sediments can provide information about the biogenic or anthropogenic source of the hydrocarbons. The Carbon Preference Index (CPI) which is used for identifying plant wax contribution versus fossil fuel contamination, varied from 1.27 to 1.33 (table 3). A CPI value higher than those indicates the predominance of odd number of carbon atoms in the hydrocarbon molecules, which 
Table 3 - Concentrations of $\mathrm{n}$-alkanes hydrocarbons ( $\mu \mathrm{g} \mathrm{kg}-1$ ) in the sediment of the colony Z3-Average for the extractions in triplicate \pm relative standard deviation expressed as a percentage. CPI - Carbon Preference Index, TAR - Terrigenous/Aquatic Ratio.

\begin{tabular}{ccccc}
\hline \hline Compound & $\mathrm{P} 1$ & $\mathrm{P} 2$ & $\mathrm{P} 3$ & $\mathrm{P} 4$ \\
\hline C14 & $92.1 \pm 10.0$ & $11.7 \pm 19.1$ & $2.7 \pm 28.5$ & $\mathrm{nd}$ \\
C15 & $62.0 \pm 19.4$ & $15.8 \pm 8.5$ & $1.9 \pm 22.8$ & nd \\
C16 & $243.6 \pm 17.5$ & $10.0 \pm 13.1$ & $3.5 \pm 16.8$ & $2.7 \pm 18.4$ \\
C17 & $968.0 \pm 23.7$ & $69.0 \pm 13.6$ & $36.9 \pm 26.3$ & $23.6 \pm 4.9$ \\
C18 & $491.5 \pm 20.3$ & $48.7 \pm 26.4$ & $17.4 \pm 26.8$ & $5.3 \pm 1.9$ \\
C19 & $462.3 \pm 21.8$ & $18.7 \pm 28.7$ & $27.7 \pm 18.1$ & $23.2 \pm 15.4$ \\
C20 & $461.4 \pm 20.5$ & $29.5 \pm 2.1$ & $37.3 \pm 18.7$ & $40.6 \pm 22.0$ \\
C21 & $336.3 \pm 20.3$ & $26.4 \pm 17.3$ & $30.9 \pm 15.3$ & $34.1 \pm 12.5$ \\
C22 & $339.2 \pm 20.5$ & $35.2 \pm 24.0$ & $32.4 \pm 16.7$ & $28.8 \pm 24.8$ \\
C23 & $353.7 \pm 23.0$ & $48.5 \pm 20.7$ & $61.2 \pm 19.6$ & $59.9 \pm 1.9$ \\
C24 & $351.8 \pm 25.3$ & $33.0 \pm 15.9$ & $20.4 \pm 19.8$ & $23.9 \pm 7.8$ \\
C25 & $220.6 \pm 21.7$ & $29.6 \pm 17.8$ & $19.2 \pm 23.4$ & $16.8 \pm 13.2$ \\
C26 & $149.7 \pm 24.0$ & $28.3 \pm 15.9$ & $17.9 \pm 18.3$ & $15.3 \pm 10.9$ \\
C27 & $317.0 \pm 15.4$ & $30.1 \pm 21.7$ & $20.9 \pm 21.7$ & $15.4 \pm 5.0$ \\
C28 & $261.1 \pm 15.0$ & $25.7 \pm 22.7$ & $16.5 \pm 20.6$ & $11.1 \pm 25.9$ \\
C29 & $221.0 \pm 15.0$ & $29.2 \pm 24.7$ & $17.7 \pm 22.2$ & $12.7 \pm 12.4$ \\
C30 & $171.5 \pm 20.5$ & $18.3 \pm 21.3$ & $9.3 \pm 21.8$ & $7.0 \pm 33.3$ \\
C31 & $181.0 \pm 17.7$ & $28.7 \pm 17.9$ & $15.7 \pm 24.1$ & $11.4 \pm 25.7$ \\
C32 & $64.1 \pm 19.9$ & $16.0 \pm 21.0$ & $8.1 \pm 22.7$ & $8.9 \pm 24.3$ \\
C33 & $39.3 \pm 21.6$ & $15.3 \pm 17.0$ & $8.6 \pm 18.0$ & $8.5 \pm 22.3$ \\
C34 & $26.8 \pm 20.4$ & $13.3 \pm 26.0$ & & \\
Total & 5868.9 & 618.1 & 417.0 & 337.6 \\
CPI & 1.31 & 1.27 & 1.33 & 1.43 \\
TAR & 0.48 & 0.85 & 0.82 & 0.84 \\
\hline \hline
\end{tabular}

is and indicative of biogenic origin (Calva et al., 2005). This was observed in all the investigated points.

The most contaminated point with $n$-alkanes hydrocarbons was point $\mathrm{P} 1$, which is located in the pier. This situation can be explained by the fact that almost fishing boats are kept in this place and also by the poor water circulation in the area, allowing these compounds to accumulate. These results are in agreement with the high concentration of organic matter found in this area (Table 1). The second most contaminated point is located between the pier and the lagoon, being this point on the course of the water/sediment flow, from the pier to the lagoon, allowing the observation of the dilution effect over the organic matter. The concentration of the $n$-alkanes hydrocarbons decreases approximately 10 times and is kept at this level in the other studied point (Figure 3 and Table 3).

Table 4 - Levels of n-alkanes hydrocarbons observed in other regions

\begin{tabular}{lcl}
\hline \hline Local & $\begin{array}{c}\mu g^{-1} \\
\text { dry basis }\end{array}$ & References \\
\hline Santos - Brazil & $1.05-4.29$ & Nishigima et al.,2001 \\
Cananéia- Brazil & $4.37-157.9$ & Nishigima et al.,2001 \\
Yellow sea - China & $0.7-15.8$ & Wu et al., 2001 \\
Patos Lagoon & $0.2-7.5$ & Medeiros et al., 2005 \\
(Rio Grande) - Brazil & $0.4-5.8$ & \\
This study &
\end{tabular}

The results have also shown the presence of low molecular weight alkanes, particularly the $\mathrm{nC} 17$, in points 1 and 2 . This compound is an indicative of the influence of aquatic organisms (algae, plankton) (Mille et al., 2007). The low molecular weight alkanes are most easily degraded, and this may explain their lower concentration in the other points.

The sum of high molecular weight $n$-alkanes concentrations ( $\mathrm{nC} 27, \mathrm{nC} 29$ and $\mathrm{nC} 31$ ) can be used to measure the inputs from terrestrial plants, whereas the sum of $\mathrm{nC} 15, \mathrm{nC} 17$ and $\mathrm{nC} 19$ indicates $n$-alkanes from aquatic sources. The terrigenous/aquatic ratio (TAR) (Mille et al., 2007) evaluates the importance of terrigenous inputs versus aquatic inputs. When aquatic sources predominate, the terrigenous/aquatic ratio (TAR) decreases to values below 1 (TAR < 1) (Mille et al., 2007). This behavior was observed in all the studied points.

\section{CONCLUSION}

The sampling point $\mathrm{P} 1$ presented higher levels of hydrocarbons than other studied points, but it is still within the range of non contaminated sites. The level found of the hydrocarbons, was mainly due to $n$ alkanes originated from weathering of soil with vascular plants and algae production. A significant amount of $n$-alkanes was found in the sediment of point $\mathrm{P} 1$ and its origin pointed to petroleum, besides algal production. The presence of an UCM in the extracts of the sediment of point P1 also corroborates the facts just mentioned. Point P2 shows the contaminants being washed away towards the lagoon. Sediment in point P3 and P4, located into the lagoon, presents alkanes of biogenic origin. Comparing the different sampling points, it is possible to observe the dilution effect of the lagoon over the analyzed compounds. In general, the sediments sampled in the investigated region presented small levels of contamination by hydrocarbons.

\section{ACKNOWLEDGMENTS}

The author Pedro José Sanches Filho thanks CAPES (Coordenação de Aperfeiçoamento de Pessoal de Nível Superior - Brazil) and REQUIMTE (Rede de Química e Tecnologia - Portugal) for financial support in developing this work.

\section{REFERENCES}

Azevedo, D.A.; Santos, C.Y.M.; Aquino Neto, F.R. 2002. Identification and seasonal variation of 
atmospheric organic pollutants in Campos dos Goytacazes, Brazil. Atmos. Environ. 36(14): 2383-2395.

Baumgarten, M.G.Z.; Niencheski L.F.H.; Veeck, L. 2001. Nutrientes na coluna da água e na água intersticial de sedimentos de uma enseada rasa estuarina com aportes de origem antrópica (RS, Brasil). Atlântica 23: 101-116.

Bisutti, I.; Hilke, I.; Raessler, M. 2004. Determination of total organic carbon - an overview of current methods. Trends in Anal. Chem. 23(10): 716-726.

Calva, L.G.; Botello, A.V.; Vélez, G.P. 2005. Composición de hidrocarburos alifáticos en sedimentos de la Laguna Sontecomapan,VER., México. Hidrobiológica 15(1): 97-108.

Colombo, J.C.; Pelletier, E.; Brochu, C.; Khalil, M.; Catoggio, J.A. 1989. Determination of hydrocarbon sources using $n$-alkane and polyaromatica hydrocarbon distribution indexes. Case study: Rio de la Pata Estuary, Argentina, Environ. Sci. Technol. 23(7): 888-894.

Commendatore, M.G.; Esteves, J. L. 2004. Natural and anthropogenic hydrocarbons in sediments from the Chubut River (Patagonia, Argentina). Mar. Pollut. Bull. 48(9-10): 910-918.

Commendatore, M.G.; Esteves, J. L.; Colombo, J. C. 2000. Hydrocarbons in Coastal Sediments of Patagonia, Argentina: Levels and Probable Sources, Mar. Poll. Bull. 40(11): 989-998.

Cordeiro, L.H.C. 2003. Hidrocarbonetos aromáticos policíclicos nos sedimentos do estuário da Lagoa dos Patos. Tese de Mestrado. Fundação Universidade do Rio Grande - FURG. 111p.

Gomes, A.O.; Azevedo, D.A. 2003. Aliphatic and Aromatic Hydrocarbons in Tropical Recent Sediments of Campos dos Goytacazes, R.J, Brazil. J. Braz. Chem. Soc. 14(3): 358-368.

Luz, L.P.; Sanches Filho, P. J.; Sousa, E. E. H.; Kerstner, T.; Caramão, E. B. 2010. Evaluation of surface sediment contamination by polycyclic aromatic hydrocarbons in colony Z3 - (Patos Lagoon, Brazil). Microchem. J. 96(1): 161-166.

Martins, C.C.; Bícego, M. C.; Taniguchi, S.; Montone, R. C. 2004. Aliphatic and polycyclic aromatic hydrocarbons in surface sediments in Admiralty Bay, King George Island, Antarctica. Antarctic Sci. 16(2): 117-122.

Medeiros, P.M.; Bícego, M.C.; Castelão, R.M.; Del Rosso, C.; Fillmann, G.; Zamboni, A.J. 2005. Natural and anthropogenic hydrocarbon inputs to sediments of Patos Lagoon Estuary, Brazil. Environ. Int. 31(1): 77-87.

Mille, G.; Asia, L.; Guiliano, M.; Malleret, L.; Doumenq, P. 2007. Hydrocarbons in coastal sediments from the Mediterranean sea (Gulf of Fos area, France). Mar. Pollut. Bull. 54(5) : 566-575.

Mirlean, N.; Andrus, V.E.; Baisch, P. 2003. Mercury pollution sources in sediments of Patos Lagoon Estuary, Southern Brazil. Mar. Pollut. Bull. 46(3) : 331-334.

Nishigima, F.N.; Weber, R.R.; Bícego, M.C. 2001. Aliphatic and aromatic hydrocarbons in sediments of Santos and Cananéia, SP, Brazil. Mar. Poll. Bull. 42(11): 1064-1072.

Pereira, W.E.; Hostettler, F.D.; Luoma, S.N.; van Geen, A.; Fuller, C.C., Anima, R.J. 1999. Sedimentary record of anthropogenic and biogenic polycyclic aromatic hydrocarbons in San Francisco Bay, California. Mar. Chem. 64(1-2): 99-113.

Sanches Filho, P.J.; Sousa, E.E.H.; Luz, L.P.; Betemps,G.R.; Kerstner, T.; Caramão, E.B. 2010. Avaliação ambiental e estudo qualitativo de hidrocarbonetos poliaromáticos da região da Colônia Z-3 - Laguna dos Patos, Pelotas - RS. Rev. Thema 7(1): 1-9.

Simpson, M.J.; Chefetz, B.; Deshmukh, A.P.; Hatcher, P.G. 2005. Comparison of polycyclic aromatic hydrocarbon distributions and sedimentary organic matter characteristics in contaminated, coastal sediments from Pensacola Bay, Florida, Mar. Environ. Res. 59(2): 139-163.

Suguio, K., 1973. Introdução à sedimentologia. $1^{\text {a }}$ Edição. Editora Edgard Blücher/EDUSP, São Paulo, 317p.

Tagliani, P.R.A.; Landazuri, H.; Reis, E.G.; Tagliani, C.R.; Asmus, M.L.; Sanches-Arcilla, A. 2003. Integrated coastal zone management in the Patos Lagoon estuary: perspectives in context of developing country. Ocean Coast. Manage. 46(910): 807-822.

Tolosa, I.; Mora, S.J.; Fowler, S.W.; Villeneuve, J.P.; Bartocci, J.; Cattini, C. 2005. Aliphatic and aromatic hydrocarbons in marine biota and coastal sediments from the Gulf and the Gulf of Oman. Mar. Pollut.Bull. 50(12) : 1619-1633.

UNEP - United Nations Environment Programme. 1992. Determination of petroleum hydrocarbons in sediments. References Methods for Marine Pollution studies.

USEPA - United States Environmental Protection Agency. 1996. Method 3540C- Soxhlet Extraction, US Environmental Protection Agency, Washington, DC.

Volkman, J.K.; Hostettler, F.D.; Neil, G.; Bavor Jr, H.J. 1992. Identification of natural, anthropogenic and petroleum hydrocarbons in aquatic sediments. The Sci. Total Environ. 112(2-3): 203-219. 
Wakeham, S.G. 1996. Aliphatic and polycyclic aromatic hydrocarbons in Black Sea sediments. Mar. Chem. 53(3-4): 187-205.

Wu, Y.; Zhang, J.; Mi, T.Z.; Li, B. 2001. Occurrence of $n$-alkanes and polycyclic aromatic hydrocarbons in the core sediments of the Yellow Sea. Mar. Chem. 76(1-2): 1-15.

Yunker M. B., Macdonald R. W., Cretney W. J., Fowler B. R., and McLaughlin F. A. 1993. Alkane, terpene, and polycyclic aromatic hydrocarbon geochemistry of the Mackenzie River and Mackenzie Shelf:
Riverine contributions to Beaufort Sea coastal sediment. Geochim. et Cosmochim. Acta 57(13): 3041-3061.

Zheng, G.J.; Richardson, B.J.; 1999. Petroleum hydrocarbons and polycyclic aromatic hydrocarbons (PAHs) in Hong Kong marine sediments. Chemosphere 38(11): 2625- 2632.

Submetido: Abril/2011 Revisado: Março/2013 Aceito: Maio/2013 